\title{
REAKTUALISASI KONSEP DASAR PENDIDIKAN ISLAM: PARADIGMA BARU DI ERA MASYARAKAT EKONOMI ASEAN (MEA) DALAM PELUANG DAN TANTANGAN
}

\author{
Surawadi ${ }^{1}$, Awad $^{2}$ \\ Universitas Islam Negeri Antasari Banjarmsin \\ Sekolah Tinggi Ilmu Tarbiyah Darul Hijrah Martapura \\ Email: surawardi@uinsan.ac.id
}

\begin{abstract}
In this era of globalization, it is necessary for the modernization process to occur in human life, due to the fulfillment of various human demands and the development of advances in the fields of science and technology, especially in the world of information and new innovations that bring drastic changes. Facing such a situation, Islamic education must also try to put its position into a strategic position not only in the context of building a complete human being, but also instilling ideal values for the life and progress of a dynamically developing society so that it can provide solutions to various problems that arise arise as a result of advances in science and technology, modernization and globalization. In addition, Islamic education is also expected to be able to build an integrative scientific and technological style construction (between spiritualism and realism) in life. Education is also the best institution in guiding human life to realize its self-actualization for a full and prosperous life in accordance with the ideals of life. All of this, of course, cannot be separated from the concept of divinity, humanity and nature which was developed in an integrative way.
\end{abstract}

Keywords: Reactualization of Islamic Education, New Paradigm

\begin{abstract}
ABSTRAK
Dalam era globalisasi ini niscayanya proses modernisasi terjadi dalam kehidupan manusia, karena berbagai pemenuhan tuntutan manusia dan perkembangan kemajuan bidang-bidang iptek, terutama dalam dunia informasi dan inovasi baru yang membawa perubahan drastis. Menghadapi keadaan yang demikian, pendidikan Islam pun mesti berupaya meletakkan posisinya kepada kedudukan yang strategis bukan saja dalam rangka membangun manusia yang utuh menyeluruh, melainkan juga menanamkan nilainilai yang ideal bagi kehidupan dan kemajuan masyarakat yang dinamis berkembang agar mampu memberikan pemecahan terhadap berbagai persoalan yang timbul sebagai akibat dari kemajuan iptek, modernisasi dan globalisasi. Selain itu, pendidikan Islam juga diharapkan mampu membangun konstruksi corak keilmuan dan teknologi yang integrative (antara spritualisme dan realism) dalam kehidupan. Pendidikan juga merupakan lembaga yang terbaik dalam membimbing kehidupan manusia untuk mewujudkan aktualisasi dirinya bagi kehidupan yang utuh dan sejahtera sesuai dengan cita-cita kehidupan. Kesemuanya ini tentu saja tidak bisa lepas dari konsep ketuhanan, kemanusiaan dan kealaman yang dikembangkan secara integratif.
\end{abstract}

Kata kunci: Reaktualisasi Pendidikan Islam, Paradigma Baru

\section{PENDAHULUAN}

Era globalisasi pada saat ini merupakan suatu proses pengintegrasian ekonomi nasional bangsa-bangsa ke dalam suatu sistem ekonomi global. Ia juga merupakan 
proses kebudayaan yang ditandai dengan adanya kecenderungan wilayah-wilayah di dunia, baik geografis maupun fisik, menjadi seragam dalam format sosial, budaya, ekonomi, dan politik. Dalam kehidupan sosial, proses global telah menciptakan egalitarianisme, di bidang budaya memicu munculnya internationalization of culture, di bidang ekonomi menciptakan saling ketergantungan dalam proses produksi dan pemasaran, dan di bidang politik menciptakan liberalisasi. Meskipun globalisasi dikampanyekan sebagai era masa depan, yakni suatu era yang menjanjikan "pertumbuhan" ekonomi secara global dan akan mendatangkan kemakmuran global bagi semua.

Tantangan pendidikan nasional bertambah karena pada era MEA salah satu tantangannya adalah arus bebas tenaga kerja terampil lintas negara ASEAN. Jika sumber daya guru di Indonesia masih diliputi berbagai kelemahan baik pada aspek kompetensi, kualifikasi, produktivitas, dan kesejahteraan, maka mereka dapat tersisih dalam persaingan regional maupun global. Untuk itu, upaya pengembangan profesionalisme guru harus menyentuh sampai aspek yang paling fundamental dalam perubahan kompetensi mereka.

Pendidikan Islam yang salah satu fungsi utamanya menanamkan ajaran Islam ke dalam kehidupan masyarakat, dalam perjalanan sejarahnya selain dipengaruhi oleh faktor sosial, ekonomi, politik dan kultural keagamaan, juga dihadapkan dengan berbagai tantangan. Atas dasar fakta demikian, maka sungguhpun rujukan utama pendidikan Islam itu adalah al-Qur'an dan Hadits, namun dalam implementasinya ia menunjukkan dinamika dan variasi yang amat beragam. Al Ainain dalam kaitan ini menegaskan bahwa pendidikan sebagai sebuah kegiatan yang bersifat sosial kemasyarakatan yang kehadirannya selalu berbeda-beda sesuai dengan corak, sifat dan kebudayaan yang berkembang pada masyarakat tersebut.

Nata mengatakan bahwa tantangan pendidikan Islam sekarang ini amat beragam demikian juga respon dan kesanggupan masyarakat untuk menghadapi tantangan tersebut amat beragam pula. Sejarah mencatat bahwa di antara lembaga-lembaga pendidikan Islam yang di masa dahulu menunjukkan kejayaan dan disegani masyarakat, hingga sekarangpun tetap jaya dan disegani masyarakat. Namun ada pula lembaga yang dahulu keredibilitasnya demikian tinggi, namun sekarang kurang terdengar lagi, bahkan nyaris tenggelam. Keadaan yang demikian itu amat tergantung kepada sejauh mana lembaga pendidikan dengan sumber daya manusia yang ada di dalamnya mampu mengatasi berbagai tantangan yang muncul.

Keberhasilan suatu pembangunan termasuk pendidikan selalu disertai dengan tantangan-tantangan baru dan bahkan dampak negatifnya sekaligus. Sebagai antisipasi diperlukan respon dan perlakuan baru yang lebih baik, termasuk dalam hal pendidikan Islam sangat diperlukan konsep pendidikan baru yang lebih Islami. Upaya mencari paradigma baru pendidikan semakin menjadi obsesi semua kalangan, karena seluruh proses kehidupan identik dengan proses pendidikan. Di samping itu, urgensi mencari dan menemukan paradigma pendidikan baru yang semakin islami itu ditentukan pula oleh kondisi objektif dunia saat ini di mana moral telah benar-benar dikesampingkan sebagai bagian esensial dari kehidupan manusia.

Dalam kaitan dengan persoalan di atas, maka tantangan yang bersifat mendasar terhadap sistem pendidikan Islam antara lain: pertama, mampukah sistem pendidikan Islam menjadi centre of excellence bagi perkembangan ilmu pengetahuan dan teknologi (Iptek) yang tidak bebas nilai. Kedua, mampukah sistem pendidikan menjadi agen pembaruan pemikiran Islam yang responsif terhadap tantangan zaman tanpa mengabaikan aspek dogmatis yang wajib diikuti. Ketiga, mampukah pendidikan Islam 
menumbuhkembangkan kepribadian yang benar-benar beriman dan bertakwa kepada Allah lengkap dengan kemampuan bernalar ilmiah yang tidak mengenal batas akhir.

Globalisasi merupakan suatu proses pengintegrasian ekonomi nasional bangsa-bangsa ke dalam suatu sistem ekonomi global. Ia juga merupakan proses kebudayaan yang ditandai dengan adanya kecenderungan wilayah-wilayah di dunia, baik geografis maupun fisik, menjadi seragam dalam format sosial, budaya, ekonomi, dan politik. Dalam kehidupan sosial, proses global telah menciptakan egalitarianisme, di bidang budaya memicu munculnya internationalization of culture, di bidang ekonomi menciptakan saling ketergantungan dalam proses produksi dan pemasaran, dan di bidang politik menciptakan liberalisasi. Jika ditinjau dari sejarah perkembangan ekonomi, globalisasi pada dasarnya merupakan salah satu fase perjalanan panjang perkembangan kapitalisme liberal yang secara teoritis sebenarnya telah dikembangkan oleh Adam Smith. Meskipun globalisasi dikampanyekan sebagai era masa depan, yakni suatu era yang menjanjikan "pertumbuhan" ekonomi secara global dan akan mendatangkan kemakmuran global bagi semua, globalisasi sesungguhnya adalah kelanjutan dari kolonialisme dan developmentalisme sebelumnya

Tantangan pendidikan nasional bertambah. Karena pada era MEA salah satu tantangannya adalah arus bebas tenaga kerja terampil lintas negara ASEAN. Jika sumber daya guru di Indonesia masih diliputi berbagai kelemahan baik pada aspek kompetensi, kualifikasi, produktivitas, dan kesejahteraan, maka mereka dapat tersisih dalam persaingan regional maupun global. Untuk itu, upaya pengembangan profesionalisme guru harus menyentuh sampai aspek yang paling fundamental dalam perubahan kompetensi mereka

Menghadapi Masyarakat Ekonomi Asia (MEA) Perguruan Tinggi dituntut dapat lebih meningkatkan kualitas lulusannya yang memiliki kemampuan di dunia

kerja. Skema AEC 2015 tentang ketenagakerjaan, misalnya, memberlakukan liberalisasi tenaga kerja profesional, seperti dokter, insinyur, akuntan, guru, dosen dan lain sebagainya. Amin Haedari menunjukkan data jumlah siswa yang ada di Indonesia mencapai angka 44 jutaan siswa diperkirakan jumlah siswa muslim berjumlah 40 jutaan siswa. Sementara jumlah siswa siswa yang ada di madrasah Ibtidaiyah sampai dengan Aliyah mencapai 8 jutaan siswa, jumlah ini sangat besar, tantangannya di era MEA adalah siswa-siswa ini calon pemimpin bangsa dan akan mengisi posisi-posisi strategis di Republik Indonesia. Mereka harus mendapatkan pendidikan agama yang baik. sebaliknya jika sektor tersebut tidak diisi oleh generasi yang tidak mendapatkan pendidikan agama yang baik, tentu akan menjadi ancaman. Sementara, data guru pendidikan agama Islam hanya berjumlah 182 ribu dan akan pensiun sekitar 20 ribu. Dari jumlah guru yang sangat sedikit ini tentu menjadi tugas besar dalam melakukan perubahan dan memberikan pendidikan agama Islam yang baik. Sedangkan data lapisan pekerjaan dilihat dari tingkat pendidikan menunjukkan bahwa usia di atas 15 tahun pada semua sektor pekerjaan masih didominasi oleh tenaga kerja lulusan pendidikan dasar (SD) sebesar 46,8\%, lulusan SMP 17\%, SMA sederajat 25\% dan Perguruan Tinggi $10,14 \%$

\section{LANDASAN TEORI}

\section{Paradigma Islam Tentang Tantangan dan Peluang Pendidikan}

Dalam kehidupan sekarang ini kita menyadari bahwa munculnya peradaban modern-industrial yang dipercepar oleh era globalisasi merupakan rangkaian dari kemajuanBarat pasca-renaissance yang membawa nilai antroposentrisme dan humanisme sekuler. Paham yang mendewakan kedigjayaan manusia dan dunia secara faktual ini mengakibatkan munculnya banyak persoalan kemanusiaan dalam bentuk krisis moral, krisis spiritual dan krisis kebudayaan dalam kehidupan manusia. 
Dalam kerangka melihat persoalan umat manusia yang cukup serius berkaitan dengan kemodernan dan era globalisasi inilah maka amat perlu dilakukan upaya reaktualisasi pemikiran keagamaan yang mampu memberikan arah sekaligus nilai dan kerangka berpikir yang tepat dalam kehidupan manusia. Paradigma al-Qur'an sebagai suatu konstruksi pengetahuan bisa memungkinkan untuk memahami realitas sosial sebagaimana al-Qur'an sendiri memahaminya. Al-Qur'an membangun konstruksi pengetahuan agar kita memiliki hikmah yang atas dasar itu dapat dibentuk perilaku yang sejalan dengan nilai-nilai normative baik pada level moral maupun social.

Pentingnya penggunaan akan budi dan hati nurani manusia telah diperintahkan alQur'an melalui perintah Iqra dalam surat al-Alaq 1-5 kaitannya bahwa era globalisasi sekarang ini merupakan suatu masa yang penuh tantangan untuk mewujudkan suatu masyarakat akademik, masyarakat yang berkembang menuju knowledge society dengan ciri utama adanya persaingan bebas dengan berlandaskan bahwa kesuksesan sangat ditentukan oleh educated person, orang yang terus mencari ilmu untuk merebut dan menguasai sains dan teknologi dengan mengandalkan akal dan pikiran.

Demikian pula Suyanto (2000) mengemukakan bahwa dalam kehidupan sekarang ini amat perlu membangun masyarakat sadar akan belajar (learning society). learning society merupakan sendi dasar yang amat penting dalam meningkatkan gairah kompetisi di dalam era globalisasi. Dari kenyataan inilah maka sangat perlu dikembangkan tiga tuntutan terhadap kualitas sumber daya manusia di era globalisasi, yaitu (1) SDM yang unggul; (2) adanya manusia yang terus menerus belajar; (3) perlunya dikembangkan nilai-nilai yang sesuai bagi kehidupan manusia di abad ke 21 .

\section{Peluang Pendidikan Islam}

Peluang pendidikan Islam seharusnya bisa ditangkap, diraih dan dimanfaatkan oleh para pemerhati pendidikan dalam rangka pelaksanaan dan implementasi nilai dan tujuan untuk menyongsong masa depan yang penuh kompetisi ditandai dengan munculnya era Masyarakat Ekonomi Asean. Adapun peluang pendidikan Islam bisa dideskripsikan di antaranya berikut ini:

1. Peningkatan fungsi dan peranan. Seperti kita ketahui beberapa tahun belakangan fungsi dan peran pendidikan Islam sangat terbatas, dan kadang-kadang terjadi diskriminasi. Outputnya tidak dapat diterima pada jenjang tertentu atau kemampuannya diragukan pada lapangan kerja tertentu. Namun sejak diberlakukannya UU No. 20 Tahun 2003 tentang Sistem Pendidikan Nasional dengan berbagai peraturan penjabarannya, fungsi dan peran lembaga pendidikan Islam mulai dari tingkat dasar hingga perguruan tinggi sudah diperluas bahkan sudah terbuka lebar. Karena itu, peluang ini harus diraih dan didayagunakan oleh segenap potensi penyelenggara pendidikan Islam.

2. Peningkatan persaingan dan antisipasi agama. Selaras dengan era globalisasi, di mana pemikiran manusia semakin kompleks dan menimbulkan kebingungan dalam masyarakat, perlu adanya pendekatan sosialisasi dan internalisasi nilai-nilai agama. Namun persoalannya, dalam kondisi yang serba rasionalis, orang menjadi tidak mudah mengambil konsep agama secara komprehensif, baik kepada peserta didik maupun kepada masyarakat luas.

3. Pengembangan kelembagaan. Kesempatan meningkatkan fungsi dan peranan lembaga pendidikan Islam dalam pengembangan dan pembinaan masyarakat seharusnya mendorong umat Islam bisa mengelola pendidikan Islam dengan lebih baik sesuai dengan perkembangan zaman. Dalam hal ini ada dua sasaran utama, yaitu perluasan bidang garapan dan peningkatan kualitas proses serta output hasil pendidikan. Peluang ini harus dimanfaatkan sebaik-baiknya, sebab bila tidak maka lembaga pendidikan Islam tidak akan mampu berkompetisi yang akhirya akan ditinggalkan umat. 
4. Kerjasama. Di era globalisasi yang penuh kompetisi, sangat sulit bagi suatu lembaga pendidikan dapat berjalan dan berkembang sendiri tanpa mau terlibat dan melibatkan pihak lain. Ini berarti solusi utamanya adalah harus mampu menciptakan kerjasama kelembagaan yang saling menguntungkan.

Terdapat empat hal yang akan menjadi fokus MEA pada tahun 2015 yang dapat dijadikan suatu momentum yang baik untuk Indonesia. Pertama, negara-negara di kawasan Asia Tenggara ini akan dijadikan sebuah wilayah kesatuan pasar dan basis produksi. Kedua, MEA akan dibentuk sebagai kawasan ekonomi dengan tingkat kompetisi yang tinggi, yang memerlukan suatu kebijakan yang meliputi competition policy, consumer protection, Intellectual Property Rights (IPR), taxation, dan ECommerce. Dengan demikian, dapat tercipta iklim kompetisi yang adil. Ketiga, MEA pun akan dijadikan sebagai kawasan yang memiliki perkembangan ekonomi yang merata, dengan memprioritaskan pada Usaha Kecil Menengah (UKM). Keempat, MEA akan diintegrasikan secara penuh terhadap perekonomian global. Berdasarkan ASEAN Economic Blueprint, MEA menjadi sangat dibutuhkan untuk memperkecil kesenjangan antara negara-negara ASEAN dalam hal pertumbuhan perekonomian dengan meningkatkan ketergantungan anggota-anggota di dalamnya. MEA dapat mengembangkan konsep meta-nasional dalam rantai suplai makanan, dan menghasilkan blok perdagangan tunggal yang dapat menangani dan bernegosiasi dengan eksportir dan importir non-ASEAN.

\section{Tantangan Pendidikan Islam}

Tantangan yang dihadapi oleh pendidikan Islam harus diantisipasi agar pendidikan bisa dilaksanakan dan diimplementasikan sesuai dengan misi dan tujuannya. Jika suatu tantangan mampu diantisipasi atau dihadapi dengan baik, seringkali tantangan itu menjadi peluang yang sangat berdaya guna, sebaliknya jika tidak mampu dihadapi dengan baik, seringkali ia menjadi kendala yang sangat mengganggu upaya pelaksanaan dan implementasi misi dan tujuan pendidikan Islam. Tantangan pendidikan Islam terus bergulir sejak masa Orde Lama hingga masa reformasi sekarang ini. Tantangan yang sekarang dihadapi adalah sejalan dengan peran yang harus dimanfaatkan oleh umat Islam untuk ikut serta terlibat dalam melakukan penataan ulang seluruh aspek kehidupan, baik di bidang ekonomi, sosial, politik, budaya, pendidikan dan sebagainya menurut cara-cara yang lebih demokratis, transparan, berkeadilan, jujur, amanah, manusiawi dan modern melalui konsep masyarakat madani yang berbasis al-Qur'an dan Sunnah Nabi. Tantangan lainnya yang dihadapi pendidikan islam adalah berkaitan dengan dampak yang ditimbulkan oleh globalisasi dunia yang didukung oleh kemajuan ilmu pengetahuan dan teknologi, khususnya teknologi informasi dan komunikasi.

Kehidupan masa mendatang yang ditandai oleh kemajuan ilmu pengetahuan dan teknologi dengan dampak yang bersifat multidimensional mengharuskan pendidikan Islam supaya bisa melahirkan manusia yang mampu menjalani kehidupan (preparing children for life), dan bukan hanya sekedar anak didik yang dapat bekerja. Pendidikan Islam harus mampu melahirkan manusia yang berorientasi ke masa depan, bersikap progresif, mampu memilih dan memilah secara baik, dan membuat perencanaan dengan baik. Pendidikan Islam juga harus mampu menghasilkan anak didik yang memiliki keseimbangan antara penggunaan otak kiri dengan otak kanan.

Lulusan pendidikan yang dihasilkan lembaga pendidikan Islam di masa sekarang dan masa yang akan datang adalah bukan sekedar anak yang mengetahui sesuatu (learning to know) melainkan juga dapat mengamalkan secara benar (learning to do), mempengaruhi dirinya (learning to be), dan membangun kemitraan dengan sesama (learning to live together). Pendidikan Islam harus menghasilkan manusia yang 
memiliki ciri-ciri sebagai berikut: (1) terbuka dan bersedia menerima hal-hal baru hasil inovasi dan perubahan; (2) berorientasi demokratis dan mampu memiliki pendapat yang tidak selalu sama dengan orang lain; (3) berpijak pada kenyataan, menghargai waktu, konsisten dan sistematik dalam menyelesaikan masalah; (4) selalu terlibat dalam perencanaan dan pengorganisasian; (5) memiliki keyakinan bahwa segalanya dapat diperhitungkan; (6) menghargai pendapat orang lain; (7) rasional dan percaya pada kemampuan Iptek; (8) menjunjung tinggi keadilan berdasarkan prestasi, efektifitas dan efisiensi.

Abuddin Nata mengemukakan tantangan-tantangan yang dihadapi pendidikan Islam di era kekinian menghadapi pertarungan ideologi-ideologi besar dunia ditandai oleh lima kecenderungan sebagai berikut. Pertama, kecenderungan integrasi ekonomi yang menyebabkan terjadinya persaingan bebas dalam dunia pendidikan. Munculnya konsep pendidikan yang berbasis pada sistem dan infra-struktur, manajemen berbasis mutu terpadu (TQM), interpreneur university dan lahirnya Undang-undang Badan Hukum Pendidikan (BHP) tidak lain, karena menempatkan pendidikan sebagai komoditi yang diperdagangkan. Kedua, kecenderungan fragmentasi politik yang menyebabkan terjadinya peningkatan tuntutan dan harapan dari masyarakat. Mereka semakin membutuhkan perlakuan yang adil, demokratis, egaliter, transparan, akuntabel, cepat, tepat dan profesional. Mereka ingin dilayani dengan baik dan memuaskan. Kecenderungan ini terlihat dari adanya pengelolaan manajemen pendidikan yang berbasis sekolah (shool based manajemen), pemberian peluang kepada komite atau majelis sekolah/madrasah untuk ikut dalam perumusan kebijakan dan program pendidikan, pelayanan proses belajar mengajar yang lebih memberikan peluang dan kebebasan kepada peserta didik, yaitu model belajar mengajar yang partisipatif, aktif, inovatif, kreatif, efektif dan menyenangkan (Paikem). Ketiga, kecenderungan penggunaan teknologi tinggi (high technologie) khususnya teknologi komunikasi dan informasi (TKI) seperti komputer. Kehadiran TKI ini menyebabkan terjadinya tuntutan dari masyarakat untuk mendapatkan pelayanan yang lebih cepat, transparan, tidak dibatasi waktu dan tempat. Keempat, kecenderungan interdependensi (saling tergantungan), yaitu suatu keadaan di mana seseorang baru dapat memenuhi kebutuhannya apabila dibantu oleh orang lain.

Kelima, kecenderungan munculnya penjajahan baru dalam bidang kebudayaan (new colonization in culture) yang mengakibatkan terjadinya pola pikir (mindset) masyarakat pengguna pendidikan, yaitu dari yang semula mereka belajar dalam rangka meningkatkan kemampuan intelektual, moral, fisik dan psikisnya, berubah menjadi belajar untuk mendapatkan pekerjaan dan penghasilan yang besar. Saat ini sebelum seseorang belajar atau masuk kuliah misalnya, terlebih dahulu bertanya: nanti setelah lulus bisa jadi apa? Dan berapa gajinya? program-program studi yang tidak dapat menjawab pertanyaan tersebut baik secara langsung maupun tidak langsung, dengan sendirinya akan terpinggirkan atau tidak diminati. Sedangkan program-program studi yang menawarkan pekerjaan dan penghasilan yang baik bagi lulusannya akan sangat diminati. Tidak hanya itu, kecenderungan penjajahan baru dalam bidang kebudayaan juga telah menyebabkan munculnya budaya pop atau budaya urban, yaitu budaya yang serba hedonistik, materialistik, rasional, ingin serba cepat, praktis, pragmatis dan instans. Kecenderungan budaya yang demikian itu menyebabkan ajaran agama yang bersifat normatif dan menjanjikan masa depan yang baik (di akhirat) kurang diminati. Mereka menuntut ajaran agama yang sesuai dengan budaya pop dan budaya urban. Dalam keadaan demikian, tidaklah mengherankan jika mata pelajaran agama yang disajikan secara normatif dan konvensional output menjadi tidak menarik dan ketinggalan 
zaman. Keadaan ini mengharuskan para guru atau ahli agama untuk melakukan reformulasi, reaktulisasi, dan kontekstualisasi terhadap ajaran agama, sehingga ajaran agama tersebut akan terasa efektif dan transformative tujuan lebih dapat dipertanggungjawabkan.

\section{HASIL PEBAHASAN}

\section{Reaktualisasi Konsep Dasar Pendidikan Islam Dalam Menjawab Peluang dan Tantangan Pendidikan}

Tilaar berpendapat bahwa abad ke 21 adalah abad perubahan besar di dalam kehidupan manusia, masyarakat abad ke-21 merupakan masyarakat transisi. Perubahan itu berdasarkan kehidupan agraris ke masyarakat industry dan informasi dengan kehidupan yang berbeda, dan diperbesar lagi dengan adanya gelombang globalisasi.

Watik Pratiknya sebagaimana dikutip Fajar, menggambarkan corak masyarakat yang berkembang di masa sekarang dan masa akan datang adalah berkembangnya penggunaan teknologi di dalam kehidupan, tumbuhnya masyarakat sadar informasi, adanya perilaku fungsional dan juga kehidupan menjadi semakin sistemik dan terbuka. Untuk itulah pendidikan yang akan datang mesti pendidikan yang strategis yang mampu memberikan kemampuan teknologis, fungsional, individual, informative dan terbuka.

Dalam era globalisasi ini niscayanya proses modernisasi terjadi dalam kehidupan manusia, karena berbagai pemenuhan tuntutan manusia dan perkembangan kemajuan bidang-bidang iptek, terutama dalam dunia informasi dan inovasi baru yang membawa perubahan drastis. Menghadapi keadaan yang demikian, pendidikan Islam pun mesti berupaya meletakkan posisinya kepada kedudukan yang strategis bukan saja dalam rangka membangun manusia yang utuh menyeluruh, melainkan juga menanamkan nilainilai yang ideal bagi kehidupan dan kemajuan masyarakat yang dinamis berkembang agar mampu memberikan pemecahan terhadap berbagai persoalan yang timbul sebagai akibat dari kemajuan iptek, modernisasi dan globalisasi. Selain itu, pendidikan Islam juga diharapkan mampu membangun konstruksi corak keilmuan dan teknologi yang integrative (antara spritualisme dan realism) dalam kehidupan. Pendidikan juga merupakan lembaga yang terbaik dalam membimbing kehidupan manusia untuk mewujudkan aktualisasi dirinya bagi kehidupan yang utuh dan sejahtera sesuai dengan cita-cita kehidupan. Kesemuanya ini tentu saja tidak bisa lepas dari konsep ketuhanan, kemanusiaan dan kealaman yang dikembangkan secara integratif.

Selanjutnya Fadjar yang mengutip pendapat Ahmad Pratiknya mengemukakan bahwa sumber daya manusia yang berkualitas menyangkut tiga dimensi: (1) dimensi ekonomi, (2) dimensi budaya, dan (3) dimensi spiritual (iman dan takwa). Upaya mengembangkan kualitas manusia lewat pendidikan perlu mengacu pada nilai tambah dari ketiga dimensi di atas, yakni nilai tambah ekonomis, nilai tambah budaya dan nilai tambah spiritual. Dalam kerangka inilah pendidikan Islam sebagai proses pengembangan manusia secara makro meliputi beberapa proses yaitu proses pembudayaan, proses pembinaan iman dan takwa (imtak) dan proses pembinaan iptek. Sejalan dengan inilah pendidikan Islam dalam pengembangan sumber daya manusia secara mikro merupakan proses transfer of knowledge, transfer of methodology, dan transfer of value. Selain itu, setiap muslim perlu menyadari dan meyakini sepenuhnya bahwa kebenaran Islam sebagai way of life, nilai-nilai dasarnya terkandung dalam kitab suci al-Qur'an sebagai wahyu Allah. Kemajuan modernisasi di sini harus dikembangkan atas dasar: (1) Allah menciptakan seluruh alam dengan haq bukan bathil (QS.16:3, 38:27; (2) Dia mengaturnya dengan segala peraturan Ilahi (Sunnatullah) yang menguasai dan pasti (QS. 7:54, 25:2), (3) sebagai ciptaan.

\section{KESIMPULAN}


Dari uraian di atas dapat disimpulkan bahwa peluang dan tantangan pendidikan Islam di Era MEA sebenarnya amat kompleks. Demikian pula respon dan kesanggupan masyarakat untuk menghadapi tantangan tersebut. Paradigm al-Qur'an tentang pendidikan bisa digunakan sebagai perumusan teori, dalam pengertian suatu konstruksi pengetahuan yang memungkinkan untuk memahami realitas. Peluang pendidikan Islam bisa meliputi: peningkatan fungsi dan peranan, peningkatan persaingan dan antisipasi agama, pengembangan kelembagaan, dan kerjasama. Tantangan pendidikan Islam yang sekarang dihadapi adalah aspek-aspek kehidupan yang meliputi faktor-faktor ekonomi, politik, sosial, budaya, pendidikan dan sebagainya, yang dituntut untuk diimplementasikan menurut cara-cara yang lebih demokratis, transparan, berkeadilan, jujur, amanah, manusiawi dan modern sesuai dengan konsep masyarakat madani yang berbasis al-Qur'an dan Sunnah Nabi.

\section{DAFTAR PUSTAKA}

Ali al-Khalil, Falsafah al-Tarbiyah al-Islamiyah di al-Qur"anul Karim, Beirut: Dar al-Fikr al-Arabiyah, 1980.

Arya Baskoro, Peluang, Tantangan dan Risiko bagi Indonesia dengan Adanya Masyarakat Ekonomi Asean, Centre for Risk Management Studies.

Arini, Filosofi dan Paradigm Islam dalam Pendidikan Agama. Yogyakarta: Aswaja Pressindo, 2019

H.A.R. Tilaar, Beberapa Aspek Reformasi Pendidikan Nasional dalam Perspektif Abad 21, Magelang: Indonesia Tiara, 1999.

Haedari, Amin, MEA, Tantangan dan Peluang Guru Pendidikan Agama Islam, http://iainptk.ac.id/mea-tantangan-dan-peluang-guru-pendidikan-agama-islam.

Kuntowijoyo, Paradigma Islam Interpretasi untuk Aksi, Bandung: Mizan, 1999.

Latifah, L., Ngalimun, N., Andi Setiawan, M., \& Haji Harun, M. (2020). Kecakapan Behavioral Dalam Proses Pembelajaran PAI Melalui Komunikasi Interpersonal. Bitnet: Jurnal Pendidikan Teknologi Informasi, 5 (2), 36-42. https://doi.org/10.33084/bitnet.v5i2.1747

Mastuhu, Memberdayakan Pendidikan Islam, Jakarta: Logos Wacana Ilmu, 1999.

Nashir, Haidar, Agama dan Krisis Kemanusiaan Modern, Yogyakarta: Pustaka Pelajar, 1997.

Nata, Abuddin, Pendidikan Islam di Indonesia: Tantangan dan Peluang, Jakarta: UIN Jakarta, 2004.

Nata, Abuddin, Tantangan dan Peluang Pendidikan Islam di Era Globalisasi, https://saepudinonline.wordpress.com/2012/12/17.

Ngalimun dan Harun Makmur. 2020. Komunikasi Bahasa Jawa dalam bentuk Sapaan Keluarga Transmigrasi di Kalimantan, Indonesia. PENDETA: Journal of Malay Language, Education and Literature. Vol. 11 No. 2. https://ojs.upsi.edu.my/index.php/PENDETA/article/view/4272

Prastowo, Andi, Perubahan Mindset dan Kesiapan Guru Sekolah Dasar dalam Persaingan Pendidikan di Era MEA, Prosiding Seminar Nasional Pendidikan Ekonomi UNY.

Suyanto, Refleksi dan Reformasi Pendidikan Islam di Indonesia, Yogyakarta: Adicita Karya Nusa, 2000 